\title{
PENGARUH PERBANDINGAN KOMPOS DAUN GAMAL (Giricidia maculata Hbr) DAN TANAH TERHADAP PERTUMBUHAN SEMAI MAHONI (Swietenia mahagoni (L) Jacq) Di POLYBAG
}

\author{
(Comparison Of Gamal Leaf Compos (Giricidia Maculata Hbr) And Soil For Growth Of \\ Mahoni Seedlings (Swietenia Mahagoni (L) Jacq) In Polybag) \\ Musdalifah $^{1}$, Retno Wulandari ${ }^{2}$ \\ ${ }^{1}$ Mahasiswa Fakultas Kehutanan Universitas Tadulako Jl. Soekarno-Hatta Km. 9 Palu, \\ Sulawesi Tengah 94118 \\ ${ }^{2}$ Staf Pengajar Fakultas Kehutanan Universitas Tadulako Jl. Soekarno-Hatta Km. 9 Palu, \\ Sulawesi Tengah 94118 \\ Email: musdalifah5234@gmail.com
}

\begin{abstract}
Global warming can be overcome by increasing human concern for the environment such as planting trees and converting forests. Mahagony (S. mahagoni(L) Jacq) is widely planted as a protective tree. The quality of seeds really determine the success of a forest planting effort. One alternative to producing good seedlings is the use of appropriate media so that they can produce healthy seedlings with optimal growth. The use of soil mixed with organic matter with a certain dose of gamal leaf compost is expected to increase seedling growth. This research conducted to determine the effect of the ratio of various doses of gamal and soil compost to the growthof mahagony seedlings in polybags. This research was conducted in December 2018 until March 2019, located in a permanent nursery BPDAS Palu-Poso, Tadulako University, Palu. This research used complete randomization design, which consisting of 4 treatments, namely $: P 0=$ soil (control), $P 1=$ soil $:$ gamal leaf compost $1: 1$, $P 2=$ soil $:$ gamal leaf compost $2: 1, P 3=$ soil $:$ gamal leaf compost 3:1. The results showed that the ratio of gamal leaf compost (G. maculataHbr)and soil had a very significant effect on the average increasein all treatments. The average increase in high, the highest is $P 1(15,59$ $\mathrm{cm})$, then $P 2(13,36 \mathrm{~cm}), P 3(11,89 \mathrm{~cm})$ and the lowest is $P 0(10,12 \mathrm{~cm})$. The average increase in number of leaves, the highest is P1 (5,5 leaves), then P2 (4,9 leaves), P3 (4,3 leaves) and the lowest is $P 0$ (3,3 leaves). The average increase in diameter, the biggest is $P 1(1,79 \mathrm{~mm})$, then $P 2(1,54 \mathrm{~mm}), P 3(1,31)$ and the smallest is $P 0(1,12 \mathrm{~mm})$. The average seed quality index results, the highest is $P 1(5,03)$, then $P 2(4,49), P 3(3,70)$ and the owest is $P 0(2,95)$.
\end{abstract}

Keywords: Compost, Soil.

\begin{abstract}
Abstrak
Pemanasan global dapat diatasi dengan meningkatkan kepedulian manusia terhadap lingkungan seperti menanam pohon dan mengkonversi hutan. Mahagony (S. mahagoni (L) Jacq) banyak ditanam sebagai pohon pelindung. Kualitas benih sangat menentukan keberhasilan upaya penanaman hutan. Salah satu alternatif untuk menghasilkan bibit yang baik adalah penggunaan media yang tepat sehingga mereka dapat menghasilkan bibit yang sehat dengan pertumbuhan yang optimal. Penggunaan tanah dicampur dengan bahan organik dengan dosis tertentu kompos daun gamal diharapkan dapat meningkatkan pertumbuhan bibit. Penelitian ini dilakukan untuk mengetahui pengaruh perbandingan berbagai dosis kompos gamal dan tanah terhadap pertumbuhan semai mahoni dalam polibag. Penelitian ini menggunakan rancangan acak lengkap, yang terdiri dari 4 perlakuan, yaitu: $\mathrm{P0}=$ tanah
\end{abstract}


(kontrol), P1 = tanah: kompos daun gamal 1: 1, P2 = tanah: kompos daun gamal 2: 1, P3 = tanah: daun gamal kompos 3: 1. Hasil penelitian menunjukkan bahwa perbandingan kompos daun gamal (G. maculataHbr) dan tanah memiliki pengaruh yang sangat signifikan terhadap peningkatan rata-rata pada semua perlakuan. Peningkatan rata-rata tinggi, tertinggi adalah $\mathrm{P} 1$ $(15,59 \mathrm{~cm})$, kemudian P2 $(13,36 \mathrm{~cm})$, P3 $(11,89 \mathrm{~cm})$ dan terendah adalah P0 $(10,12 \mathrm{~cm})$. Ratarata peningkatan jumlah daun, tertinggi adalah P1 (5,5 daun), kemudian P2 (4,9 daun), P3 (4,3 daun) dan terendah adalah P0 (3,3 daun). Peningkatan diameter rata-rata, terbesar adalah P1 $(1,79 \mathrm{~mm})$, kemudian P2 (1,54 mm), P3 (1,31) dan yang terkecil adalah P0 (1,12 mm). Hasil indeks kualitas benih rata-rata, tertinggi adalah P1 $(5,03)$, kemudian P2 $(4,49)$, P3 $(3,70)$ dan owest adalah P0 $(2,95)$.

\section{Kata kunci: Kompos, Tanah.}

\section{PENDAHULUAN}

Pemanasan global dapat diatasi dengan meningkatkan kepedulian manusia terhadap lingkungan seperti menanam pohon dan melestarikan hutan. Pohon adalah mesin biologis yang sangat berguna dan mampu mengurangi polusi udara. Pohon dan tumbuhan lain menggunakan karbon dioksida yang merupakan polutan di udara untuk berfotosintesis dan menghasilkan oksigen yang digunakan makhluk hidup lain untuk bernafas. Kemampuan ini akan semakin terasa apabila pohon-pohon dan tumbuhan lain berkumpul dan membentuk hutan. Hutan mampu memberikan udara yang bersih yang bisa digunakan makhluk hidup. Karena itulah hutan disebut sebagai paru-paru dunia. Hutan harus dilestarikan keberadaannya karena hutan bisa menjaga keseimbangan lingkungan dan kehidupan di bumi (Ahmad 2011).

Rehabilitasi lahan merupakan salah satu kegiatan penting yang harus dilakukan secara konseptual dalam menangani krisis lingkungan. Begitu pentingnya sehingga rehabilitasi sudah merupakan program nasional yang dilaksanakan diseluruh Indonesia. Rehabilitasi lahan merupakan suatu usaha memulihkan kembali, memperbaiki, dan meningkatkan kondisi lahan yang rusak supaya dapat berfungsi secara optimal baik sebagai lahan produksi, pengatur tata air, ataupun sebagai unsur pelindung alam dan lingkungan (Soepardja 1991).
Dalam mendukung kegiatan rehabilitasi lahan yang ditujukan pada lahan-lahan kritis, maka faktor penting yang harus dipenuhi dalam upaya pengelolaannya adalah diketahuinya informasi tentang teknik budidaya jenis pohon serta tindakan silvikultur yang tepat. Salah satunya adalah pengembangan jenis Mahoni (S. mahagoni (L) Jacq) yang harus di lestarikan (Ishak dan Mulyana 2006).

Mahoni (S. mahagoni (L) Jacq) banyak di tanam sebagai pohon pelindung karena sifatnya yang tahan panas dan memiliki daya tahan panas serta memiliki daya adaptasi yang baik terhadap berbegai kondisi tanah sehingga tetap bertahan menghiasi tepi jalan, terasa sejuk dan rindang di beberapa daerah. Tanaman ini di kembangkan pada awalnya di wilayah Jawa sejak jaman penjajahan Belanda. Kayu mahoni mempunyai nilai ekonomis yang cukup tinggi dan bagus sehingga dibudidayakan untuk keperluan sumber bahan baku industri. Kualitas kayunya keras dan memiliki warna kemerahan, sangat baik digunakan untuk meubel, furniture, barang-barang ukiran dan kerajinan tangan lainnya (Kementrian Kehutanan 2011).

Salah satu alternatif untuk memproduksi semai yang baik adalah penggunaan media yang sesuai bagi pertumbuhan semai sehingga dapat menghasilkan semai yang sehat dengan pertumbuhan yang optimal. Penggunaan bahan organik yang dicampur dengan tanah diharapkan mampu 
meningkatkan pertumbuhan semai. Penambahan bahan organik pada media tumbuh semai memiliki peran yang cukup besar terhadap perbaikan sifat fisika, kimia, dan biologi tanah yang akan mempengaruhi pertumbuhan semai tersebut (Simanungkalit 2006). Dari uraian tersebut, maka diperlukan penelitian tentang pengaruh perbandingan kompos daun Gamal (G. maculata $\mathrm{Hbr}$ ) dan tanah terhadap pertumbuhan semai Mahoni (S. mahagoni (L) Jacq) dipolybag. Penelitian ini bertujuan untuk mengetahui pengaruh berbagai takaran kompos daun Gamal ( $G$. maculata Hbr) dan tanah terhadap pertumbuhan semai Mahoni (S. mahagoni (L) Jacq) dipolybag.

\section{METODE PENELITIAN}

Penelitian ini dilaksanakan selama tiga bulan, yakni pada bulan Desember 2018 sampai Maret 2019, bertempat di Persemaian Permanen BPDAS Palu-Poso, Universitas Tadulako, Palu. Bahan-bahan yang digunakan yaitu: semai Mahoni umur 3 bulan yang memiliki tinggi, diameter, dan jumlah daun yang relatif sama,tanah berasal dari STQ, kompos daun gamal, label, polybag ukuran 20x15 dan air. Alat-alat yang digunakan yaitu: kaliper, mistar, computer atau laptop, alat tulis-menulis, kalkulator, kamera, skop, oven, timbangan analitik dan ember.

\section{Rancangan Penelitian}

Penelitian ini menggunakan metode Rancangan Acak Lengkap (RAL) yang terdiri atas 4 perlakuan yaitu:

$$
\begin{aligned}
& \text { P0 }=\text { Tanah }(\text { Kontrol }) \\
& \text { P1 }=\text { Tanah }: \text { Kompos daun Gamal 1:1 } \\
& \text { P2 = Tanah }: \text { Kompos daun Gamal 2:1 } \\
& \text { P3 = Tanah }: \text { Kompos daun Gamal 3:1 }
\end{aligned}
$$

\section{Variabel Pengamatan}

Variabel pengamatan penelitian ini yaitu sebagai berikut :

1. Tinggi semai, pengukuran tinggi semai (cm) dilakukan dengan cara mengukur tinggi semai dari pangkal batang hingga pucuk pada minggu pertama setelah ditanam dan minggu terakhir pengamatan (12 minggu setelah tanam).

2. Jumlah helai daun, dengan cara menghitung daun yang telah berkembang sempurna.

3. Diameter batang $(\mathrm{mm})$, dilakukan dengan cara mengukur diameter semai dari pangkal akar.

4. Indeks Mutu Bibit dilakukan pada akhir pengamatan, menggunakan cara Dickson (1960) dalam Hendromono (1994) dengan Rumus:

$$
I M B=\frac{\text { bobot kering batang }(\mathrm{gr})+\text { bobot kering akar }(\mathrm{gr})}{\frac{\text { Tinggi }(\mathrm{cm})}{\text { Diameter }(\mathrm{cm})}+\frac{\text { bobot kering batang }(\mathrm{gr})}{\text { bobot kering akar }(\mathrm{gr})}}
$$

\section{Analisis Data}

Analisis data dengan menggunakan analisis sidik ragam (uji F) yang digunakan yaitu Rancangan Acak Lengkap (RAL) dengan menggunakan rumus model matematis sebagai berikut :

Dimana :

$$
Y_{i j}=\mu+a_{i}+E_{i j}
$$

$\mathrm{Y}_{\mathrm{ij}} \quad=$ Hasil pengamatan pada perlakuan ke-i, dan ulangan ke-j

$\mu=$ Nilai rata-rata umum pertumbuhan semai

$\mathrm{a}_{\mathrm{i}} \quad=$ Faktor perlakuan pada taraf ke- $\mathrm{i}$

$\mathrm{E}_{\mathrm{ij}} \quad=$ Kesalahan percobaan/galat/eror

$\mathrm{I}=\mathrm{j} \quad=1,2,3,4,5$

Apabila analisis sidik ragam uji $\mathrm{F}$ menunjukkan pengaruh yang berbeda nyata, dilakukan uji lanjut dengan uji BNT taraf 5\%. 


\section{HASIL DAN PEMBAHASAN}

Pertambahan Tinggi

Tabel 1. Analisis Sidik Ragam Pertambahan Tinggi (cm) semai Mahoni (Swietenia mahagoni (L) jacq)

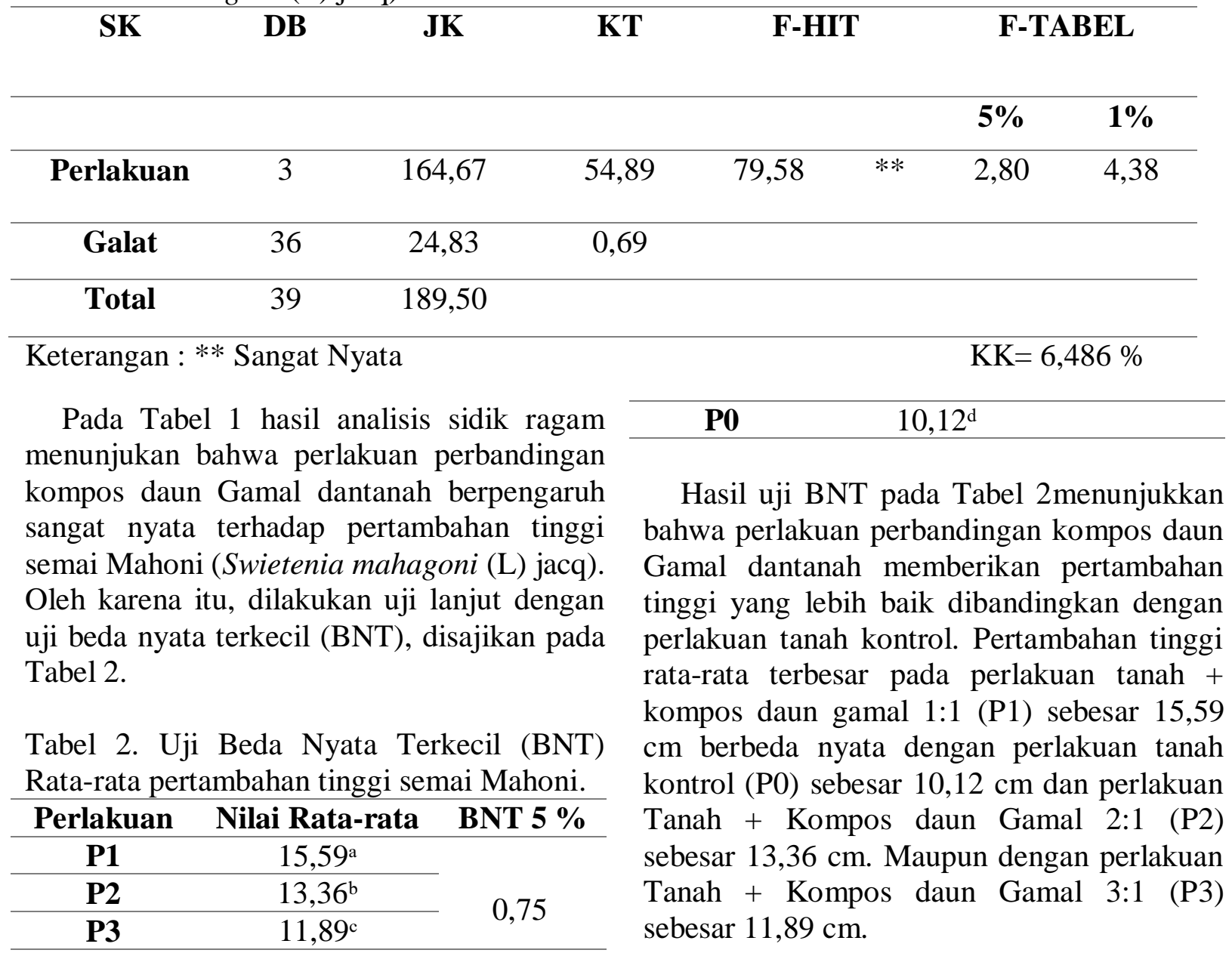

Keterangan : Angka yang diikuti huruf sama berbeda tidak nyata taraf $5 \%$

\section{Pertambahan Daun}

Tabel 3. Analisis Sidik Ragam pertambahan jumlah daun semai Mahoni (Swietenia mahagoni (L) jacq)

$\begin{array}{llllll}\text { SK } & \text { DB } & \text { JK } & \text { KT } & \text { F-HIT } & \text { F-TABEL }\end{array}$

\begin{tabular}{cccccccc}
\hline & & \multicolumn{3}{c}{} & & $\mathbf{5 \%}$ & $\mathbf{1 \%}$ \\
\hline Perlakuan & 3 & 26,40 & 8,80 & 20,31 & $* *$ & 2,80 & 4,38 \\
\hline Galat & 36 & 15,60 & 0,43 & & & & \\
\hline Total & 39 & 42,00 & & & & & \\
\hline
\end{tabular}

Keterangan : ** Sangat Nyata

$\mathrm{KK}=14,63 \%$ 
Pada Tabel 3 hasil analisis sidik ragam menunjukan bahwa perlakuan perbandingan kompos daun Gamal dantanah berpengaruh sangat nyata terhadap pertambahan jumlah daun semai Mahoni (Swietenia mahagoni (L) jacq). Oleh karena itu, dilakukan uji lanjut dengan uji beda nyata terkecil (BNT), disajikan pada Tabel 4.

Tabel 4. Uji Beda Nyata Terkecil (BNT) Ratarata pertambahan jumlah daun semai Mahoni (helai)

\begin{tabular}{ccc}
\hline Perlakuan & $\begin{array}{c}\text { Nilai Rata- } \\
\text { rata }\end{array}$ & BNT 5 \% \\
\cline { 1 - 2 } P1 & $5,5^{\mathrm{a}}$ & \multirow{2}{*}{0,60} \\
\cline { 1 - 2 } P2 & $4,9^{\mathrm{b}}$ & \\
\cline { 1 - 2 } P3 & $4,3^{\mathrm{c}}$ & \\
\cline { 1 - 2 } P0 & $3,3^{\mathrm{d}}$ & \\
\hline
\end{tabular}

Keterangan : Angka yang diikuti huruf sama berbeda tidak nyata pada taraf $5 \%$

Hasil uji BNT pada Tabel 4 menunjukan bahwa perlakuan perbandingan kompos daun Gamal dantanah memberikan pertambahan jumlah daun yang lebih baik dibandingkan dengan perlakuan tanah kontrol. Pertambahan jumlah daun (helai) rata-rata terbesar pada perlakuan tanah + kompos daun gamal 1:1 (P1) sebesar 5,5 helai berbeda nyata dengan perlakuan tanah kontrol (P0) sebesar 3,3 helai dan perlakuan Tanah + Kompos daun Gamal 2:1 (P2) sebesar 4,9 helai. Maupun dengan perlakuan Tanah + Kompos daun Gamal 3:1 (P3) sebesar 4,3 helai.

\section{Pertambahan Diameter}

Tabel 5. Analisis Sidik Ragam Pertambahan Diameter (mm) semai Mahoni (Swietenia mahagoni (L) jacq)

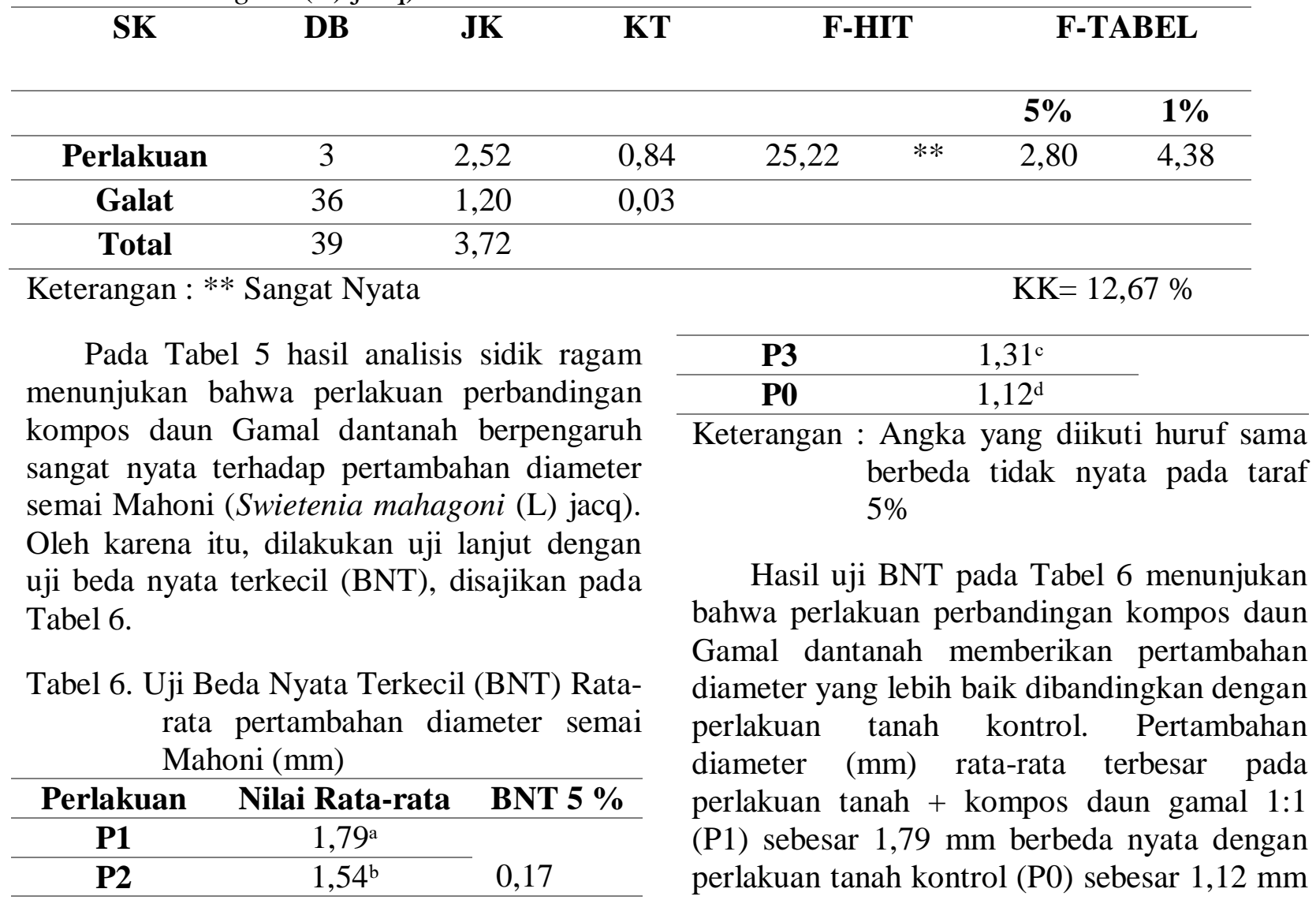


dan perlakuan Tanah + Kompos daun Gamal 2:1 (P2) sebesar 1,54 mm. Maupun dengan perlakuan Tanah + Kompos daun Gamal 3:1 (P3) sebesar 1,31 mm.

\section{Indeks Mutu Bibit}

Tabel 7.Indeks Mutu Bibit pada Mahoni (Swietenia mahagoni (L) jacq) umur 12 minggu

\begin{tabular}{|c|c|}
\hline Perlakuan & Indeks Mutu Bibit \\
\hline S0 & 2,95 \\
\hline S1 & 5,03 \\
\hline S2 & 4,49 \\
\hline S3 & 3,70 \\
\hline
\end{tabular}

Menurut Dickson (1960) dalam Hendromono (1994) bahwa apabila indeks mutu bibit lebih dari 0,09 maka bibit dinyatakan layak untuk ditanam. Nilai indeks mutu bibit (P0) sebesar 2,95, (P1) sebesar 5,03, (P2) sebesar 4,49, dan (P3) sebesar 3,70. Nilai tertinggi diperoleh (P1) yaitu sebesar 5,03 . Berdeda sangat nyata oleh perlakuan kontrol (P0) yaitu 2,95. Olehnya itu, semua bibit yang dihasilkan dari perlakuan-perlakuan tersebut layak untuk ditanam.

Hasil penelitian menunjukkan bahwa perlakuan tanah :kompos daun gamal (Gliricidia maculataHbr) mengalami pertumbuhan sangat nyata baik dari segi tinggi, helai daun dan diameter pertumbuhan dibandingkan perlakuan tanah (kontrol).Pertumbuhan terbaik pada tanah + kompos daun gamal (G. maculataHbr) 1:1 (P1) baik dari segi tinggi, helai daun dan diameter dibandingkan perlakuan tanah kontrol (P0) dan tanah + kompos daun gamal (G. maculataHbr) 1:3 (P3), berbeda nyata dengan tanah + kompos daun gamal $(G$. maculataHbr) 1:2 (P2). Menurut Purwanto (2007) bahwa gamal yang berumur satu tahun memiliki 3-6\% N; 0,31\% P; 0,77\% K; 15$30 \%$ Serat kasar. Hal ini membuktikan bahwa kombinasi penambahan pupuk kompos daun gamal dengan perbandingan 1:1 (P1) kedalam media tanah dapat memperbaiki sifat fisik tanah, menambah unsur hara yang dibutuhkan oleh tanaman, menggemburkan tanah, meningkatkan populasi mikroba tanah dan mempercepat daya serap unsur hara dan daya simpan air tanah serta mempunyai draenase dan aerasi yang baik. Bahan organik yang tersedia bagi mikroorganisme dalam memperbaiki struktur tanah (Buckman dan Brady, 1982).

Tinggi tanaman merupakan ukuran yang sering diamati baik sebagai indikator pertumbuhan maupun sebagai parameter yang digunakan untuk mengukur pengaruh lingkungan atau perlakuan yang diterapkan. Hal ini didasarkan kenyataan bahwa tinggi tanaman merupakan ukuran pertumbuhan yang paling mudah diamati. Pertambahan tinggi tanaman merupakan suatu hasil dari metabolisme tanaman berupa pertambahan ukuran sel tumbuh baik besar dan panjang sel. Pertambahan tinggi tanamn juga merupakan hasil dari aktifitas jaringan meristem yang giat membelah sehingga jumlah sel meningkat. Tinggi tanaman mahoni diukur dari pangkal akar sampai pada pucuk batang. Disamping pengaruh lingkungan, tinggi tanaman juga sebagai indikator pertumbuhan untuk mengukur pengaruh suatu perlakuan yang diberikan (Lakitan, 1995).

Pertumbuhantanaman dipengaruhi oleh ketersediaan unsur hara dalam tanah seperti unsur Nitrogen (N), Fospor (P), dan Kalium $(\mathrm{K})$, ketiga jenis unsur hara tersebut yang paling banyak dibutuhkan oleh tanaman karena setiap unsur hara memiliki fungsi yang sangat penting bagi pertumbuhan tanaman (Maspary dan Wiria, 1986).

Pertambahan diameter pada hakikatnya merupakan hal yang sama dengan pertambahan tinggi, karena keduanya adalah hasil aktifitas unsur hara dan nutrisi yang diserap tanaman dari media tumbuh. Seperti yang dikemukakan oleh Suhendi (1982) bahwa unsur $\mathrm{P}$ (Fospor) memegang peranan penting di dalam pembelahan sel dan 
perkembangan jaringan meristematik seperti pada kambium. Meningkatnya unsur $\mathrm{P}$ didalam media tanam menyebabakan perkembangan jaringan meristematik dan pembentukan sel kambium ke arah samping akan meningkat, sehingga akan menyebabkan diameter akan bertambah.

Pertambahan diameter diakibatkan oleh meningkatnya jaringan pembulu seperti xilem dan floem yang terdapat pada batang akibat unsur hara yang diserap oleh tanaman seperti $\mathrm{Ca}$ yang berfungsi merangsang pembentukan bulu-bulu akar, berperan dalam pembuatan protein atau bagian yang aktif dari tanaman, memperkeras batang tanaman dan sekaligus merangsang pembentukan biji, menetralisir asam-asam organik yang dihasilkan pada saat metabolisme Kalsium yang terdapat dalam batang dan daun dapat menetralisirkan senyawa suasana keasaman tanah (Maspary dan Wiria, 1986).

Daun merupakan organ tanaman yang mensintesis makanan untuk kebutuhan tanaman maupun sebagai cadangan makanan. Maka pengamatan pada daun sangat diperlukan sebagai indikator pertumbuhan tanaman dan juga dapat digunakan sebagai data pendukung dalam menjelaskan proses pertumbuhan. Daun mempunyai klorofil yang berperan dalam melakukan fotosintesis. Jika tempat tumbuh untuk melakukan proses fotosintesis lebih banyak, maka hasilnya lebih banyak juga (Duaja, 2012).

Ketersediaan unsur hara Nitrogen yang terdapat pada pupuk kompos daun Legum seperti Nitrogen (N) yang dibutuhkan pada saat pertumbuhan tanaman. Sebagai mana dijelaskan oleh (Maspary dan Wiria, 1986) bahwa unsur Nitrogen diperlukan untuk pembentukan atau pertumbuhan bagian vegetatif tanaman, seperti daun, batang dan akar. Berperan penting dalam hal pembentukan hijau daun yang berguna sekali dalam proses fotosintesis. Membentuk protein, lemak dan berbagai persenyawaan organik.
Meningkatnya mutu tanaman penghasil daundaunan. Meningkatkan perkembangbiakanmikroorgannisme dalam tanah. Hal ini berarti unsur Nitrogen berperan dalam pembentukan trubusan atau daun muda pada tanaman. Sementara unsur Magnesium merupakan pusat molekul klorofil pada daun tanaman dan kofaktor untuk banyak enzim yang mengaktifkan fosforilasi pada fotosintesis, metabolisme Nitrogen dan sintesis protein.

\section{KESIMPULAN DAN SARAN}

Berdasarkan hasil penelitian disimpulkan bahwa perbandingan kompos daun gamal dan tanah yang berbeda memberikan pengaruh yang berbeda nyata terhadap semua pertumbuhan semai Mahoni (Swietenia mahagoni (L) Jacq). Perlakuan kompos daun gamal : tanah 1:1 (P1) memberikan pengaruh terbaik padas semua parameter pertumbuhan yaitu tinggi $(15,59 \mathrm{~cm})$, daun $(5,5$ helai), dan diameter $(1,79 \mathrm{~mm})$. Berdasarkan hasil penelitian maka perlu dilakukan penelitian lanjutan menggunakan kompos yang berbeda dalam pembibitan Mahoni (Swietenia mahagoni (L) Jacq) untuk mendapatkan bibit yang berkualitas baik.

\section{DAFTAR PUSTAKA}

Ahmad, B. E. P., 2011. Peran kearifan lokal dalam menjaga kelestarian hutan. Jurnal Pemikiran Islam. Universitas Islam Indonesia Yogyakarta. Vol. 16 No. 1. EISSN : 2356-2420

Buckman, H.O. dan Brady, 1982. Ilmu Tanah. Terjemahan of The Nature and Properties of Soils. Oleh Soegiman. Bharata Karya Aksara, Jakarta.

Duaja, M.D., 2012. Pengaruh Bahan Dosis
Kompos
Cair
Pertumbuhan Kacang Buncis
Terhadap 
(Laktuva santiva sp). Jurnal Ilmu Pertanian 1 (1) : 11-12.

Hendromono, 1994. Pengaruh Media Organik dan Tanah mineral terhadap mutu bibit Pterygota alata Roxb.Buletin Penelitian Hutan, 617, 55-64.

Ishak, Y. Dan Mulyana, O., 2006. Pengaruh Dosis Pupuk Organik Terhadap Pertumbuhan Mahoni (Swietenia mahagoni) pada Lahan Alang-Alang di Samboja, Kalimantan Timur. Jurnal Penelitian Hutan dan Konservasi Alam Vol. IV No. 4 : 377-384, 2007.

Kementrian Kehutanan, BPDAS Solo. 2011. Info tanaman hijau.http://www.bpdassolo.net/index.p hp/tanaman-kayu-kayuan/tanamanmahoni. Diakses 25 september 2017.
Lakitan, B., 1995. Fisiologi Tumbuhan dan Perkembangan Tanaman. Raja Grafindo Persada, Jakarta.

Maspary, S. Dan Wiria, 1986. Fungsi Unsur Hara dalam Proses Pertumbuhan dan Perkembangan Tanaman, Gramedia Jakarta.

Purwanto, I. 2007. Mengenal lebih dekat Leguminoceae.Penebar Swadaya. Jakarta.

Simanungkalit, R. D. M., 2006. Pupuk Organik Dan Pupuk Hayati. Balai Besar Litbang Sumberdaya Lahan Pertanian. Balai Penelitian dan Pengembangan Pertanian. Bogor.

Soepardja, E. 1991. Penanganan lahan kritis dari masa ke masa. Bandung : Angkasa.

Suhendi, H. 1992. Pengaruh pupuk N, P, dan Kapur terhadap pertumbuhan Laporan No.407. Balai Penelitian Hutan. Bogor. 